This has been published by Text \& Talk.

Please cite as:

D’Hertefelt, Sarah \& An Van linden. 2017. Independent conditional clauses with argumentative function in Dutch. Text \& Talk 37(5): 587-614.

DOI: https://doi.org/10.1515/text-2017-0020

\begin{abstract}
This study offers an analysis of independent conditional clauses (ICCs) that are used with argumentative functions in spoken Dutch. ICCs are used as arguments when they serve to motivate the speaker's implied standpoint regarding a preceding propositional content, termed the trigger. Two basic types of argumentative ICCs can be distinguished, which are termed 'direct' and 'indirect' arguments. Direct arguments express a contextually given premise on the basis of which a conclusion about the speaker's standpoint regarding a preceding trigger can be drawn. Indirect arguments, by contrast, express a condition that - if it had held - would have warranted the conclusion, but its counterfactual interpretation resulting from hypothetical backshift signals that the speaker knows that this condition is not fulfilled, and hence that the implied standpoint regarding a trigger is not valid either. We argue that direct and indirect ICCs instantiate independent instances of epistemic non-predictive conditionals and hypothetical predictive conditionals (in the sense of Dancygier) respectively, and that they set up propositional-logic arguments of different classic forms, i.e. the modus ponendo ponens form (direct ICCs) and the denying the antecedent form (indirect ICCs). However, they do not explicitly express the conclusion of the argument, as they lack a main clause, but leave it to be inferred by the addressee.
\end{abstract}

\title{
Keywords
}

independent conditional clauses, reasoning, propositional logic, semantic prosody, Dutch 


\section{Independent conditional clauses with argumentative function in Dutch}

Sarah D'Hertefelt ${ }^{\mathrm{a}, \mathrm{b}} \&$ An Van linden ${ }^{\mathrm{c}, \mathrm{b}}$

${ }^{a}$ Vrije Universiteit Brussel, Belgium

${ }^{\mathrm{b}}$ University of Leuven - KU Leuven, Belgium

cUniversity of Liège, Belgium

\section{Introduction ${ }^{1}$}

This article deals with independent conditional clauses that are used with argumentative functions in spoken Dutch, as exemplified in (1) and (2). Studies discussing the structure type of conditional clauses that are not accompanied by a main clause have often taken a pragmatic perspective, focusing on the illocutionary or discourse functions of these structures. Examples include Boogaart and Verheij (2013) for Dutch, Weuster (1983), Oppenrieder (1989) and Günthner (1999) for German, Laury et al. (2013) for Finnish and Swedish, Stirling (1999), Panther and Thornburg (2003) and Kaltenböck (2016) for English, Patard (2014) for French, Vallauri (2004) for Italian, and Schwenter (2016) for Spanish. Evans and Watanabe (2016) also include contributions about non-Indo-European languages. In many of the more recent studies, these independent subordinate-marked clauses are described as instances of 'insubordination', i.e. the "conventionalized main clause use of what, on prima facie grounds, appear to be formally subordinate clauses" (Evans 2007: 367). The illocutionary or discourse functions that have been identified for such structures comprise the expression of requests (e.g. If you could open the window?), wishes (e.g. If only he could have seen this!), threats (e.g. If you dare touch my car...!), and evaluation (e.g. If a person can't pass an opinion...) (see D'Hertefelt [2015] for a detailed description of these uses). However, in spite of the extensive existing literature on these constructionalized uses of independent conditional clauses, independent conditional clauses with argumentative functions like (1) and (2) so far appear to have largely escaped attention in the literature, with the exception of a brief discussion by Panther and Thornburg (2003: 140-141), who label such English structures as If that's the way they want it as 'expressives' (see D'Hertefelt 2015). ${ }^{2}$

In (1), two speakers converse about their experiences at cash desks in American supermarkets, where poorly paid employees - typically pensioners - put your groceries in bags, and, if requested, carry them to your car. Speaker A says it is common to give a one-dollar tip for the carrier service, while the packing service is generally not rewarded.

$$
\begin{aligned}
& \text { A: ' } k \text { heb ze ook wel 'ns bij de kassa dollar gegeven hoor 'k zeg nou je hoeft } \\
& \text { niet mee te lopen } \\
& \text { [trigger] } \\
& \text { walk with me" }
\end{aligned}
$$

\footnotetext{
${ }^{1}$ Work on this article was supported by project GOA/12/007, funded by the Research Council of the University of Leuven (KU Leuven). Authorship of this paper is shared jointly. D'Hertefelt submitted the first version of the manuscript in 2014, but was unable to continue work on the paper due to a change of employment. She invited Van linden, who co-supervised her (2015) $\mathrm{PhD}$, to revise the manuscript. Van linden subsequently revised the manuscript substantially in response to the comments of three anonymous referees, whom we thank for their input. Changes in the argument and the form of the paper were substantial enough to warrant joint authorship. We would also like to thank Jean-Christophe Verstraete for valuable comments on earlier versions of this article.

${ }^{2}$ We will analyze such structures as direct argumentative ICCs, as will be detailed below.
} 


\section{$[\ldots]$}

B: $\quad$ ja zou dat 't enige zijn wat ze verdienen dan

yes, would that be the only money they make then?

A: $\quad$ het zijn gepensioneerden

they're pensioners

hebben alleen 't pensioentje

only have a small pension

$[\ldots]$

A: $\quad$ ze moeten [het] ook echt van de fooi hebben

they really have to rely on the tip

$[\ldots]$

A: $\quad$ nou ik voel me wel 'ns bezwaard

well, I sometimes feel troubled

denk je van je loep je loopt daar zoals een luxe tante

then you think you are walking there like some sort of posh lady

B: $\quad j a$

yes

A: $\quad$ alsofje zelfje boodschappen niet kunt dragen

as if you can't carry your groceries yourself

$\begin{array}{llllll}\text { maar ja } & \text { als } & \text { 't } & \text { hun inkomen } & \text { is } \\ \text { but yes } & \text { COND it } & \text { their income } & \text { be.3SG.PRS }\end{array}$

'but well, if it's their income'

B: $\quad j a$.

$(\mathrm{CGN})^{3}$

yes

Example (2) is excerpted from a conversation between a young couple about another couple, i.e. Speaker A's sister and her partner. That partner recently got a new job for which he sometimes has to work in the weekend.

A: $\quad$ ja maar ' $k$ denk dat ze wel weer kwaad was gisteren

[trigger]

yeah but I think she was angry again yesterday

B: $\quad$ ja maar hij heeft dat toch niet veel gedaan

yes, but it's not like he's done that a lot

weekend

weekend

als dat nu elke week zou zijn dat hij de

COND DEM PRT every week would be.INF that he the

\footnotetext{
${ }^{3}$ In the Corpus Gesproken Nederlands (CGN; 'Spoken Dutch Corpus'), the following transcription conventions are used: $g g g$ marks clearly audible, non-linguistic speaker sounds, e.g. laughter; $x x x$ stands for unintelligible or non-transcribed speech.
} 


$\begin{array}{llllll}\text { zaterdag } & \text { de } & \text { zondag } & \text { moet } & \text { werken } & \text { en } \\ \text { Saturday } & \text { the } & \text { Sunday } & \text { have.to.3SG.PRS } & \text { work.INF } & \text { and } \\ \text { zo } & & & & & \\ \text { like.that } & & & & \end{array}$

\author{
'if he had to work Saturdays and Sundays every week, that kind of thing' \\ A: $\quad$ nee nee dat is uh $\mathrm{hm}$ \\ no no that's erm \\ B: $\quad$ maar moet ie daar in de fabriek zelf zitten of zo of moet ie moet ie ergens \\ naartoe \\ but does he have to be in the factory or does he have to go somewhere else? \\ $(\mathrm{CGN})$
}

The independent conditional clauses (henceforth ICCs) marked in bold in (1) and (2) can be considered arguments because they motivate the speaker's ${ }^{4}$ standpoint regarding a (set of) proposition(s) from the preceding discourse, which we call 'trigger', as indicated in the examples. However, since these conditional clauses lack a main clause, the actual standpoint they defend is not explicitly expressed. Rather, argumentative ICCs orient the addressee's attention towards an implied conclusion concerning the speaker's standpoint, a conclusion which the addressee has to draw on their own. In (1) the ICC functions as an argument motivating the speaker's implied approval or acceptance of the trigger: 'if it's these people's income, [then it's okay that they carry my groceries to my car]'. Speakers use ICCs like (1) to express a 'given' assumption in conditional form. In (2), the ICC functions as an argument motivating the speaker's implied disapproval or rejection of the trigger. In addition, (2) is different from (1) in that it involves an extra step in the argumentation by virtue of its counterfactual nature, marked by the future-in-the-past form zou zijn (literally 'would be'). Specifically, the speaker expresses a condition that - if it had held - would have warranted the conclusion (implied acceptance of the trigger), but its counterfactual interpretation resulting from hypothetical backshift (cf. Dancygier 1993, 1998) - which is absent in (1) - indicates that the speaker knows that this condition is not fulfilled, and hence that the implied standpoint of acceptance is not valid either. The argumentative ICC in (2) thus implies: "if it were the case that he has to work weekends every week, then it would be understandable that she was angry; however, since he does not have to work weekends every week, she has no reason to be angry'. Because of the extra step involved in the argumentation in structures involving hypothetical backshift, like (2), these will be called 'indirect' arguments. Structures without hypothetical backshift like (1) will be called 'direct' arguments.

The structure of this article is as follows. Sections 2 and 3 will offer descriptive analyses of the two basic types of argumentative ICCs that can be distinguished in Dutch, i.e. direct (1) and indirect arguments (2) respectively. We will discuss their semantic and pragmatic properties, as well as their argumentative orientation. In the process, attention will be paid to the conversational dynamics of the discourse and the rhetorical effects the two types of ICC may have. The distinction between the two types will be informed by Dancygier's $(1993,1998)$

\footnotetext{
${ }^{4}$ In this study, the label 'speaker' generally refers to the person producing the argumentative ICC, and 'addressee' refers to their interlocutor(s).
} 
typology of conditionals. Direct arguments will be argued to instantiate independent instances of non-predictive - epistemic - conditionals, while indirect arguments will be analyzed as independent instances of predictive - hypothetical - conditionals (Dancygier 1993, 1998). In Section 4, the two argument types will be related to reasoning patterns of propositional logic. We will argue that direct arguments are interpreted to set up an argument of the modus (ponendo) ponens form, while indirect arguments set up the argumentative form of denying the antecedent, which is considered a fallacy within formal logic, but can still have legitimate uses within informal logic insofar as "the argument provides some reason for its conclusion" (Duarte d'Almeida and MacDonald 2016: 36-37; emphasis original). Finally, Section 5 will recapitulate our major findings and present some questions for further research.

The data on which this study is based come from the Corpus Gesproken Nederlands (CGN, 'Spoken Dutch Corpus'), and to a lesser extent from a personal corpus of internet material (IC). The relevant examples were retrieved by using both general queries (specifying turn-initial position of als 'if') and lexically more specific queries (including maar ja als 'but well, if', cf. [1]), and were drawn either from the CGN sub-corpora comprising (multi-speaker) dialogues or from such interactive webpages as blogs and fora, which are taken to contain data that come close to spontaneous spoken discourse. In total, a set of 20 argumentative ICCs were studied in detail, which included 14 direct and 6 indirect arguments. In general, D'Hertefelt's (2015) exploratory study unearthed far fewer argumentative uses of ICCs than constructionalized uses like wishes and requests. Nevertheless, our native speaker intuitions suggest that both types of argumentative ICCs are productive in Dutch, especially in colloquial language use.

\section{Direct argumentative ICCs}

Direct argumentative ICCs serve to motivate the speaker's implied acceptance of something that was said in the preceding discourse. They thus function as pro-arguments with respect to a preceding trigger, cf. (1). More examples are given in (3) and (4). In (3), the speaker talks about their experiences in booking first-class tickets for a show by the Tiroler band Kastelruther Spatzen, which turn out to be surprisingly expensive, especially in view of the limited number of people on stage (about six performers). This show is then compared to the Holiday On Ice show. In (4), three friends are talking about a fourth friend, Madelon, who has been laid off and is still unemployed.

(3) [...] ik moet eerlijk zeggen bij Holiday On Ice ben je ook veel geld kwijt [trigger] I have to admit, if you go to Holiday On Ice you also have to pay a lot of money

$\begin{array}{lllllll}\text { maar } & \text { ja } & \text { als je } \quad \text { ook ziet } & \text { hoeveel } & \text { mensen } & \text { daar } \\ \text { but } & \text { yes } & \text { COND 2SG } & \text { also see.2SG.PRS } & \text { how.many } & \text { people } & \text { there } \\ \text { op } & \text { 't } & \text { podium } & \text { staan } & & \\ \text { on } & \text { the } & \text { stage } & \text { stand.3PL.PRS } & & \end{array}$

'but then again, if you (sg) see how many people are on stage there' (CGN) 
A: $\quad$ dus nu is ze hard op zoek ook

so now she's very busy looking [for work], too

B: $\quad$ dus daarom heb ik dus ook uh de vakantie even nog niet geboekt want uh ja wij wouden eigenlijk wat verder [trigger] so that's why I haven't booked erm the holiday yet because erm yes we wanted to go [on holiday] a bit further afield

maa ja als Madelon geen werk heeft
but yes COND Madelon no job have.3SG.PRS
'but well, if Madelon doesn't have a job'
oh dat zei je ja
oh, that's what you said, yes

In (3), the ICC motivates the speaker's implied acceptance of the trigger: the high number of people involved in the Holiday On Ice show makes it acceptable that the tickets for the show are expensive. The same goes for (4): the fact that Madelon does not have a job motivates why B has postponed booking tickets for their holiday so far.

The unexpressed conclusion of direct argumentative ICCs always involves a type of attitudinal evaluation, i.e. the speaker's assessment towards the situation referred to in the trigger (cf. Van linden [2012: ch. 2] on modal-evaluative meaning). The speaker's very use of a direct argument signals that they feel that their standpoint is somehow controversial; if this were not the case, an argument would hardly be needed (cf. van Eemeren et al. [1996: 5] on the controversiality typically associated with arguments). The trigger typically refers to something the speaker evaluates negatively (e.g. as unethical, unpleasant, or unexpected). The speaker's implied acceptance of the trigger is observed to be inspired by different types of attitudinal assessments; the specific type depends on the content of both the trigger and ICC. In (1), the trigger concerns Speaker A's practice of a behavior ('I paid pensioners to carry my groceries to my car') that is evaluated negatively by the same speaker, as it sometimes makes A feel troubled. Speaker A uses the ICC to clear their conscience: 'if it's the pensioner's income [then it's morally acceptable that I have them carry my groceries to my car]'. The implied standpoint in (1) thus is deontic in nature (as defined by Nuyts et al. [2010], with deontic qualification pertaining to both potential SoAs and propositional contents presupposed true; see Van linden and Verstraete [2011] for an alternative view). By contrast, the implied standpoint in (3) is mainly based on market-economic principles. The trigger refers to the high price of the tickets for Holiday On Ice; high prices are generally regarded as unpleasant (this negative evaluation is not explicitly expressed). Therefore, implied acceptance of the organizers of the show setting high prices needs extra back-up in the form of an ICC; the high number of performers renders it economically justifiable that tickets are expensive. ${ }^{5}$ In (4), the trigger refers to the fact that Speaker B has so far refrained from booking holiday tickets. B's implied standpoint is an attitudinal assessment in terms of likeability (also termed 'boulomaic modality' in Nuyts 2005, 2006): although B may think it is unpleasant that they have not booked tickets yet, the reason

\footnotetext{
${ }^{5}$ Note that this standpoint has some deontic flavor to it as well; the speaker in (2) tacitly accepts the free market system, whereas one may just as well consider it unethical.
} 
behind this - Madelon's unemployment - makes this unpleasant fact bearable, or boulomaically acceptable. The examples thus indicate that it is the specific content of both the trigger and the ICC that determine the nature of the attitudinal assessment that is implied by the ICC and left to be inferred by the addressee.

In examples (1), (3) and (4) the trigger and ICC are produced by the same speaker, but this need not be the case. Consider example (5), in which A has just told B about going through extreme emotional states while seeing everything in colors in a marijuana-induced trip. Note that the trigger is produced by A, while the ICC is uttered by B.

(5) A: maar pas op daarvoor heb 'k ik uh denk drie vier weken eigenlijk bijna niks gesmoord

[start trigger]

but hold on, before that [i.e. the marijuana-induced trip] I had hardly been smoking marijuana, erm, I think for three or four weeks

B: $\quad m m m$

$\mathrm{mmm}$

A: $\quad$ in de week of zo hè

during the week, that is

B: $\quad j a$

yes

A: $\quad$ pff

pff

niks

nothing

na gewoon van uh geen goesting niet meer hebben

[end trigger]

well just because I didn't feel like it anymore

B: maar ja als ge bezig zijt overdag

but yes COND 2SG busy be.2SG.PRS during.the.day

'but well, if you're busy during the day'

A: $\quad$ ja maar ja

yes but, well

B: $\quad$ hebt gij dat

did you [experience] this?

allee bij mij was dat toch uh

well, this is what I experienced, anyway

$(\mathrm{CGN})$

In (5), the trigger refers to A's achievement of not having smoked marijuana for a couple of weeks. A evaluates this achievement as unexpected, as is evident from the interjection pas op 'beware; hold on'. Speaker B uses an ICC to express their implied acceptance of A's achievement, but at the same time the ICC also rebuts A's evaluation of their own achievement as unexpected: 'if you're busy during the day [then it's (to be) expected (or unsurprising) that you do not feel like smoking marijuana, and hence that you managed to refrain from doing so 
for about four weeks]'. Both A's and B's (implied) standpoints assess the trigger proposition in terms of mirativity, which involves the expression of both speaker surprise (Delancey 2001: 369) (A's utterance) and its opposite meaning, i.e. lack of surprise (B's utterance) (cf. SimonVandenbergen and Aijmer 2007: 37; Gentens et al. 2016; Van linden et al. 2016). More generally, different-speaker direct arguments express concurrence with the interlocutor on the propositional content of the trigger, but at the same time also express disagreement with regard to their interlocutor's (implied) evaluation of that content. They thus form mainly cooperative reactions to their interlocutor's turn. In single-speaker direct argumentative ICCs, by contrast, there is not any disagreement; the ICC allows the speaker to come out with a nuanced stance towards the trigger proposition.

Irrespective of the type of attitudinal assessment invoked by the ICC and the (non-)identity of the speakers producing the trigger and ICC, all direct arguments function in a similar fashion, which can schematically be represented as in Figure 1 (based on example (1)).

[Figure 1 about here]

In this schema, the arrows pointing in opposite directions illustrate the contrast between the speaker's implied (controversial) standpoint the ICC orients to, and the 'uncontroversial' standpoint that is in line with the explicit or implicit evaluation of the trigger. This contrast is typically made explicit with the combination maar ja 'but well' preceding the ICC, which is a combination of the adversative coordinator maar 'but' and the interjection ja 'yes; well'.

As can be gathered from the paraphrases given for the examples of direct ICCs, these constructions do not express conditional relations in the content domain in the sense of Sweetser (1990), in which the protasis expresses an assumption on the basis of which the speaker arrives at a prediction conveyed in the apodosis (with sequential and causal relations between $\mathrm{p}$ and $\mathrm{q}$, e.g. If it rains, the match will be canceled). Rather, they express assumptions on the basis of which conclusions can be drawn, and thus instantiate independent instances of non-predictive conditionals, specifically of the epistemic or 'inferential' type (Dancygier 1993: 423-426, 1998: 86-88; Sweetser 1990: 116). An important difference between predictive and non-predictive conditionals relates to the use of verb forms. While predictive ones show backshift (see Section 3), non-predictive conditionals are not backshifted, i.e., the verb forms refer to the time they indicate (cf. Dancygier 1993: 405). All the examples given above show present-tense marked verb phrases that have present time reference; they refer to assumptions that hold at the time of utterance. (Note that in predictive conditionals like If it rains, the match will be canceled, the protasis refers to the future but indicates the present, cf. Dancygier [1993: 405-406].) Yet, these assumptions are not presented by the speaker as known to them, but they are marked as 'epistemic distance' between speaker and content. The kind of unassertability signaled in epistemic conditionals thus is that the speaker does not take the responsibility for asserting $\mathrm{p}$. In the examples, the degree of epistemic distance marked by the non-predictive protases is rather low. In (1) and (4), the ICC refers to information that the speaker had already explicitly asserted in the preceding discourse, and thus clearly belongs to the common ground (cf. Clark 1996). In (3), it has not been mentioned in the preceding discourse how many people are on stage in Holiday On Ice shows, but the speaker assumes that the addressee has access to that 
information. In (5), the degree of epistemic distance may be somewhat higher, as the ICC refers to information that the addressee has privileged access to (how the addressee spends the day). The 'contextual givenness' of direct argumentative ICCs will become even more clear in Section 4 , in which a parallel is drawn with arguments of the classic modus ponens form.

\section{Indirect argumentative ICCs}

While direct argumentative ICCs are used to motivate the speaker's implied acceptance of a preceding trigger, indirect arguments are used to motivate the speaker's implied rejection of a trigger, as in (2), or their acceptance of a trigger containing a negative evaluation, as in (11) below. Another example (10) is given, in which Speaker A is telling Speaker B about her three grandchildren. The excerpt focuses on the middle one called Lies, who - to A's mind - has always been lagging behind her fellow preschoolers.

(10) A: en dat was zo meer ja ggg ja die CLB's die dan zeiden van uhm ja stuurt ze toch maar naar 't eerste studiejaar [trigger]

and it was more like yes ggg yes those CLBs [Pupil Guidance Centres] they said ehm yes do send her to first grade anyway

$[\ldots]$

ze is echt gemotiveerd

she's really motivated

ze is nen doorzetter

she's a go-getter

enzovoort enzovoort

and so on and so on

B: $\quad j a$

yes

A: $\quad$ maar het blijft dus wel wel uh ja ja het blijft een vraag

but it still remains, well well ehm yes yes, it still remains a question

$[\ldots]$

ze faalt wel veel hè

she does fail a lot, doesn't she

allee ja ik bedoel ze ziet ook wel dat ze zo zo goed niet is als de anderen hè

well I mean, she also realizes she's not as good as the others, doesn't she?

B: $\quad$ ja

yes

ge moet ze dus eigenlijk ggg begeleiden

so you have to $g g g$ guide her

$[\ldots]$

A: $\quad$ het is zo ja zo een klein meisje nog

she's still such a small girl

't is zo echt nog zo een heel klein meisje hè

she really still is such a very little girl, isn't she 


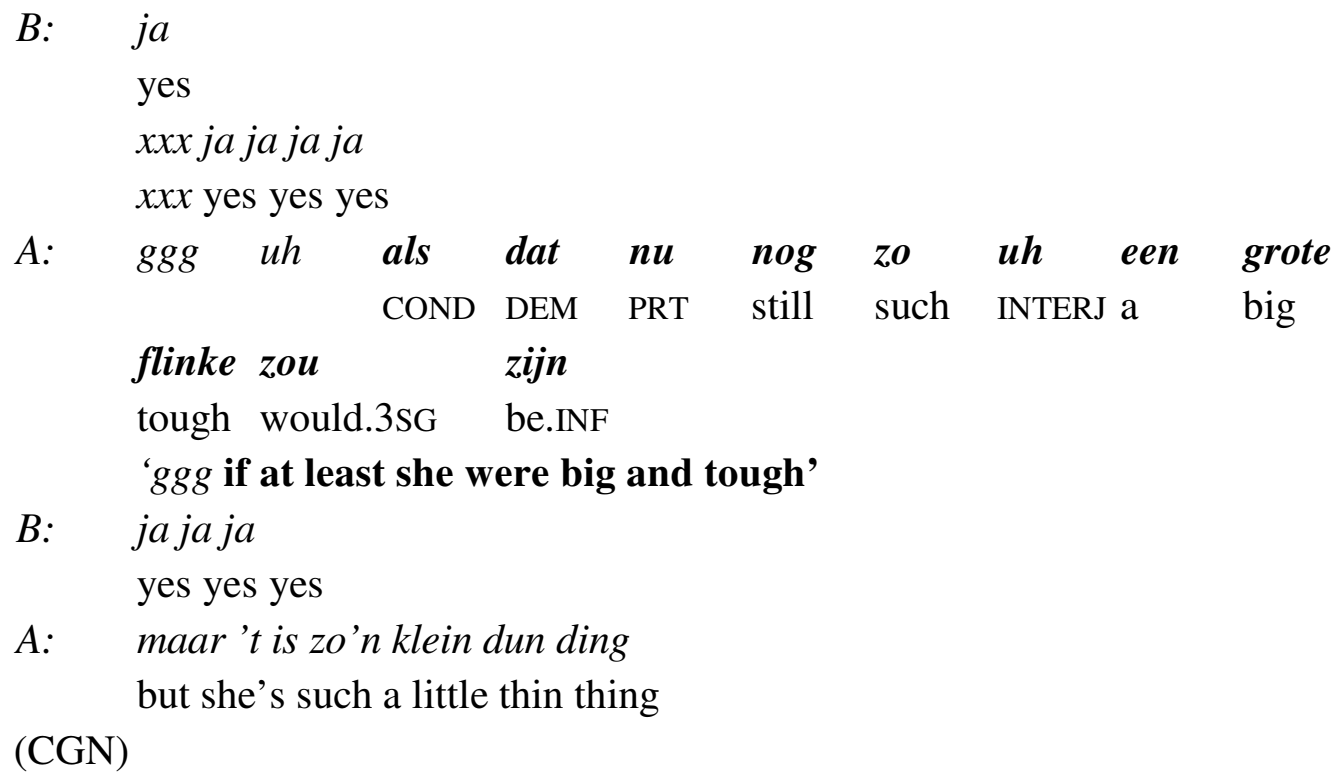

In (10), the trigger refers to a reported directive speech act: the Pupil Guidance Centres told Speaker A's daughter to send her daughter Lies to first grade. The ICC is used to motivate Speaker A's implied disapproval of this recommendation, i.e. she thinks it had better not be complied with, as Lies still is a little thin girl.

An important feature of indirect ICCs is that - unlike direct ICCs - they are backshifted, i.e. "the time reference intended by the speaker is systematically later than the time referred to by the verb form in its prototypical (non-conditional) uses" (Dancygier 1993: 406; emphasis in original), which is characteristic of predictive conditionals as opposed to non-predictive ones. Crucially, indirect arguments involve hypothetical backshifting, showing either weak hypothetical forms like the future-in-the-past form zou zijn (literally 'would be') in (2) and (10), or strong hypothetical forms like the future-in-the-past perfect form gelegen zou hebben (literally 'would have lain') in (14) (see Section 4) and the past perfect was gebleven (literally 'had stayed') in (11). ${ }^{6}$ While direct arguments can be analyzed as contextually given assumptions, indirect ones cannot be interpreted as assumptions, not even provisional ones. They can only be entertained as hypotheses, as the speaker holds other assumptions that contradict the assumption in $\mathrm{p}$ (Dancygier 1993: 409, 1998: 50). Strong hypothetical forms indicate that the counterevidence the speaker chooses to ignore in making a prediction is very strong. In fact, they represent the possibility that $p$ holds as completely excluded, and thus signal that the prediction in the apodosis is not valid. The weak hypothetical forms used in the examples here refer to the present rather than the future - they show state verbs rather than event verbs - and hence also indicate that the counterevidence is very strong. Because of their counterfactual interpretation, indirect arguments are double-layered. At the primary ('propositional') level, the ICC in (10) refers to a potential SoA that - if it had held - would have been a pro-argument with respect to the trigger: 'if Lies is big and tough [then it's okay to

\footnotetext{
${ }^{6}$ Note that - unlike English - Dutch allows future-in-the-past (perfect) forms in predictive conditional protases. Strictly speaking, the mechanism of backshift applies to the past and past perfect verb forms only, but its function, i.e. the marking of degrees of unassertability of the conditional relation between $\mathrm{p}$ and $\mathrm{q}$, does apply to the future-in-the-past (perfect) forms as well.
} 
send her to first grade]'. Therefore, at this level the ICC orients towards an expected or uncontroversial standpoint in the conclusion, i.e. compliance with a well-intended recommendation. At the counterfactual level, however, the hypothetical backshift in the ICC signals that the speaker knows that 'Lies is not big and tough', but that she is still a little thin girl, as she comments in the turns preceding and following the ICC. The counterfactual layer thus inverts the argument towards the opposite conclusion, i.e. implied disapproval of the trigger. Indirect counter-arguments like (10) can be schematically represented as in Figure 2.

[Figure 2 about here]

Hypothetical backshifting exactly signals the existence of counterevidence to the addressee, who may not share the speaker's knowledge (Dancygier 1993: 410). This forms another difference with direct argumentative ICCs, which are contextually given. Indirect arguments need not be contextually given (this is nevertheless the case in [10]); they may as well rely on information that is accessible to the speaker only, which is the case in (11). Up to the occurrence of the ICC in (11), the speaker has not mentioned how many things had gone wrong with her general practitioner. Indirect argumentative ICCs may thus present information that is new to the addressee.

While the ICC in (10) functions as a counter-argument, indirect arguments may as well function as pro-arguments, like (11). In such cases, the ICC motivates a negative evaluation contained in the trigger proposition. (11) is taken from a webpage entitled 'The importance of a good general practitioner' (GP). Mijn vorige huisarts was niet alleen minder slim - ze wist ook minder van het menselijk
lichaam dan ikzelf. En dat is irritant. Tevens gevaarlijk.

My previous general practitioner was not only less smart - she also knew less about the human body than I do. And that's irritating. And dangerous at the same time.

[... anecdote about an error made by the doctor, who had prescribed a double dose of tetanus vaccine for the speaker's baby]

$\mathrm{Nu}$ weet ik niet wat precies het effect is van $2 x$ zoveel Tetanusvaccin in je baby's minidonder, maar ik werd niet bepaald gelukkig van het idee.

Well, I'm not sure what the precise effect is of a double dose of tetanus vaccine in your baby's minibody, but the idea didn't exactly make me happy.

$\begin{array}{llllllll}\text { En } & \text { als } & \text { het } & \text { daar } & \text { nu } & \text { bij } & \text { was gebleven... maar }[\ldots] \\ \text { and } & \text { COND } & \text { it } & \text { there } & \text { PRT } & \text { with } & \text { be.3SG.PST stay.PAPA but }\end{array}$

'And if at least that had been all... but [...]'

[... anecdote about another error made by the same doctor]

(http://groenevrouw.nl/het-belang-van-een-goede-huisarts/, 18/03/2015)

Within the line of argumentation developed in (11), the ICC functions as an argument in favor of the speaker's claims outlined in the trigger, i.e. that her GP is less competent than herself (who is not trained in medicine), and that this is irritating and dangerous. The argument thus serves to motivate a negative evaluation of a person's competence and of a situation. Like (10), 
(11) is double-layered: at the propositional level, the ICC refers to an SoA that could have been a counter-argument with respect to the trigger: 'if the GP hasn't made any more mistakes, then perhaps the GP isn't so bad after all, and the situation is not that irritating or dangerous'. Consequently, at this level the ICC orients towards a more or less expected or uncontroversial standpoint, i.e. disapproval of a trigger involving a negative evaluation. Again, the hypothetical backshift indicates that the speaker knows that 'this has not been all', but that the GP has been making more mistakes, which is substantiated in the speaker's next anecdote. The speaker thus signals that the negative evaluation of the GP and the situation cannot be redeemed, and the ICC functions as an argument in favor of the speaker's implied acceptance of this trigger. Schematically, indirect pro-arguments can be represented as in Figure 3. Although indirect argumentative ICCs can be used to express both pro-arguments (11) and counter-arguments (10), the speaker's implied standpoint generally has negative semantic prosody (cf. Sinclair 2004; Morley and Partington 2009), either because it rejects the trigger proposition (counterarguments) or because it supports a negative evaluation of a person or situation (proarguments).

[Figure 3 about here]

In the examples given so far the trigger and ICC are uttered by the same speaker (11), by different interlocutors (2), and by the same speaker who represents speech produced by a different speaker (10). While in single-speaker direct arguments the speaker is taking a nuanced stance on the trigger proposition, in single-speaker indirect arguments like (11), the speaker is far less subtle and sophisticated. This is why in examples like (10), in which the speaker incorporates someone else's speech in the trigger, the indirect argument orients towards quite unsubtle disagreement with the represented speaker. In the different-speaker example in (2) above, the speaker uses the ICC to condemn the behavior of the she-person referred to in the trigger ('since her partner doesn't have to work weekends every week, [it's not understandable that she's angry]'). The ICC in (2) might be interpreted to fuel an argument between Speakers $\mathrm{A}$ and B. Speaker A (producing the trigger) is the sister of the she-person whose anger is frowned upon by Speaker B (producing the ICC). B might have uttered the ICC to pre-empt protest from A (his partner), who could have decided to defend her sister. Of course, this need not be the case; A's evaluation of her sister's behavior may just as well have been the same as B's. More generally, indirect argumentative ICCs lack the nuance characteristic of direct ones, and are hence potentially more aggressive in a conversation. As suggested by a referee, speakers use them to forestall any possible objection to their implied point of view, by pretending to be willing to go along with the trigger proposition (in the case of counter-arguments) or a rebuttal of a negative evaluation (in the case of pro-arguments) if a sufficient condition were fulfilled.

The process of 'counterfactual' reversal typical of indirect arguments involves scalarity, which is formally reflected. The argument on the propositional level that is inverted or 'negated' by the counterfactual interpretation always refers to what the speaker considers to be a sufficient condition for the negated (uncontroversial) standpoint. For instance, in example (11), one could think of a number of arguments against the trigger like 'she apologized for her mistakes, she made these mistakes because she was temporarily very confused ...'. However, the condition 
that no new mistakes were made is taken as a sufficient condition for the speaker's disapproval of the trigger: fulfilment of this condition already suffices for the speaker to reconsider their negative evaluation. The hypothetical backshift in the ICC indicates that the speaker knows that this sufficient condition is not fulfilled; hence, the negative evaluation in the trigger cannot be redeemed and the ICC orients towards approval of the trigger. This polarity reversal triggered by the scalar interpretation of the condition (i.e. as a sufficient one) equally applies to indirect counter-arguments (10). Formal reflection of this scalarity is found in the use of the scalar particle nog 'still' in (10), and in the use of scalar 'at least' in the English translations of (10) and (11). In (2), the time adverbial 'every week' sets up a scale of frequency of the weekend work that arouses anger in Speaker A's sister. The clash between the propositional layer and the counterfactual layer is often formally expressed by the adversative conjunction maar 'but' introducing a statement that confirms the falsity of the propositional layer immediately following the indirect argument. Same-speaker examples (10) and (11) are cases in point. A final formal property of indirect arguments is that they are typically marked by the modal particle nu/nou. ${ }^{7}$ However, further research on this particle is needed to describe its use in indirect argumentative ICCs in more detail.

\section{Argumentative ICCs and propositional logic}

In the discussions in Sections 2 and 3 it became clear that together with the trigger proposition, argumentative ICCs set up arguments the conclusion of which is left to be inferred by the addressee. More specifically, we will argue that direct arguments launch reasoning patterns of the modus (ponendo) ponens form, ${ }^{8}$ while indirect arguments invoke the argumentative form of denying the antecedent. While the classic forms of such reasoning patterns of propositional logic always include a conclusion, this component is lacking in the arguments focused on here, as the argumentative conditional clauses are not accompanied by a main clause.

As argued by van Eemeren et al. (1996: 14), not expressing the motivated standpoint is by no means exceptional in argumentation patterns. However, in argumentative ICCs this orientation towards an implied conclusion is constructionally present, because conditional protases (at least in preposed conditionals) always function as 'stepping stones' towards a possible conclusion (Harder 1997: 446). This 'orienting' property of argumentative ICCs is particularly clear if we compare direct and indirect arguments with their non-conditional counterparts:

alsof je zelf je boodschappen niet kunt dragen

as if you can't carry your groceries yourself

$\begin{array}{llllll}\text { a. maar ja } & \text { als 't } & \text { hun inkomen } & \text { is } \\ \text { but yes } & \text { COND it } & \text { their income } & \text { be.3SG.PRS }\end{array}$

\footnotetext{
${ }^{7}$ Note that $n u / n o u$ is not typical of backshifted predictive conditionals in general, but it is typical of indirect arguments.

${ }^{8}$ We thank an anonymous referee for pointing out the parallel between direct argumentative ICCs and classic arguments of the modus ponendo ponens form.
} 


\section{'but well, if it's their income' \\ b. maar ja het is hun inkomen \\ but yes it be.3SG.PRS their income \\ 'but well, it's their income'}

(13) A: ja maar ' $k$ denk dat ze wel weer kwaad was gisteren

yeah but I think she was angry again yesterday

B: $\quad$ ja maar hij heeft dat toch niet veel gedaan

Yes, but it's not like he's done that a lot

$\begin{array}{lllllll}\text { a. als dat } & \boldsymbol{n u} & \text { elke week } & \text { zou zijn dat hij de } & \text { hij } \\ \text { COND DEM } & \text { PRT } & \text { every week } & \text { would be.INF that he the } & \text { he } \\ \text { zaterdag } & \text { de } & \text { zondag } & \text { moet werken } & \text { en } & \\ \text { Saturday } & \text { the } & \text { Sunday } & \text { has.to work.INF } & \text { and } \\ \text { zo } & & & & & & \\ \text { like.that } & & & & & & \end{array}$

\section{'if he had to work Saturdays and Sundays every week, that kind of thing'}

b. hij moet niet elke week de zaterdag de

he has.to NEG every week the Saturday the

zondag werken

Sunday work.INF

'he doesn't have to work Saturdays and Sundays every week'

In (12a), the conditional subordinator als 'if' marks the construction explicitly as a premise, on the basis of which a specific conclusion concerning the speaker's standpoint can be drawn. This orientation towards an implied speaker standpoint is not present in (12b). The same applies to the constructions in (13): in (13a), the conditional subordinator marks the construction as an assumption which leads to a prediction concerning the speaker's standpoint; the hypothetical backshift makes it clear that this assumption does not hold and therefore implies the opposite of the predicted standpoint. In the non-conditional form of the argument in (13b), the speaker merely presents an argument against 'her' being angry, but without explicitly marking this argument as leading to a certain standpoint. Note that in the non-conditional form in (13b) negative polarity is explicitly marked, while in the conditional form in (13a) it is the counterfactual interpretation resulting from hypothetical backshifting that reverses the polarity value (see Section 3).

Their shared conditional form thus makes direct and indirect argumentative ICCs very well suited to motivating speaker standpoints, because they explicitly orient the addressee's attention towards a conclusion for the argument presented in the ICC. While in most cases the conclusion remains implied, we also found cases in which the conclusion is produced by either the addressee or the speaker who uttered the ICC, cf. (14) below. In (14), drawn from the singlespeaker sub-corpora of the CGN, a boy named Sander is watching a great fire destroying an old warehouse. Biking away from the fire, he gets a flat tire, and he finds that it is a hot dagger lying at the edge of the bike lane that caused the puncture. 
it's strange that this dagger is so hot

$\begin{array}{lllllll}\text { Als hij } & \text { nu vlak bij } & \text { de } & \text { brand gelegen } & \text { zou hebben } \\ \text { COND he } & \text { PRT close by the fire lie.PAPA } & \text { would have.INF } \\ \text { had het } & \text { gekund } & & & & & \\ \text { had it } & \text { can.PAPA } & & & & & \end{array}$

'If it had lain close to the fire, it would have been possible.' maar er liggen weilanden tussen de loods van Oevers en het fietspad but there are meadows in between the Oevers warehouse and the bike lane. $(\mathrm{CGN})$

(14) does not instantiate an argumentative ICC, but rather a syntactically complete argumentative (predictive) conditional construction, in which the protasis expresses a condition that - if it had held - would have licensed the conclusion expressed in the apodosis. However, the backshifted verb form (gelegen zou hebben 'would have lain') signals that the speaker knows that this condition is not fulfilled, as explicitly mentioned in the next turn, and hence that the conclusion is not warranted either. That is, Sander still has no explanation for how this hot dagger came to lie on the bike lane.

In structures without a main clause like the ICCs studied here, however, the addressee is not offered the conclusion concerning the speaker's standpoint, but has to infer this on their own. In such cases, the use of a conditional structure functions as an 'invitation' towards the addressee to take up an active part in the speaker's argumentative reasoning process. We found cases in which the addressee in fact does try to produce the conclusion. The use of an argumentative ICC therefore implies more addressee involvement than the use of syntactically complete constructions like (14).

The two types of argumentative ICCs studied both leave the conclusion to be inferred by the addressee; yet they differ in the type of reasoning pattern they set up. This becomes especially clear if we cast them in terms of propositional logic. Direct argumentative ICCs evoke arguments of the classic modus ponens form, which has two premises. The first premise is the conditional claim that $\mathrm{p}$ implies $\mathrm{q}(\mathrm{p} \rightarrow \mathrm{q})$. The second premise is that $\mathrm{p}$, the antecedent of the conditional claim, is true. Given the truth of these premises it can be logically deduced that q, the consequent of the conditional claim, must be true as well. Interestingly, Dancygier (1993: 427) already noted that analyses of conditionals based on material implication within propositional logic center on non-predictive epistemic conditionals rather than predictive ones. Direct argumentative ICCs, we argue, convey $\mathrm{p}$ in a modus ponens form, i.e. the antecedent in the conditional first premise, and at the same time function as the second premise, i.e. it is the case that $\mathrm{p}$. That is, direct arguments express a 'given' assumption in conditional form. In logical arguments launched by direct ICCs, q is never fully explicitly expressed; it combines the propositional content of the trigger with the speaker's attitudinal qualification of it that is implied by the construction-in-context. In (15) we apply the modus ponens form to example (1). A classic example of the modus ponens form is included also (in italics). 
$\mathrm{p} \rightarrow \mathrm{q} \quad$ If [it is these persons' income] $]_{\mathrm{p}}$, then [it is morally acceptable that I have them carry my groceries to my car $]_{\mathrm{q}}$ If [Socrates is a man], then [Socrates is mortal] $q$

$\mathrm{p} \quad$ It is these persons' income

Socrates is a man

Hence, q Hence, it is morally acceptable that I have them carry my groceries to my car

Hence, Socrates is mortal

While in formal logic arguments are evaluated in terms of validity and soundness - the classic example in (15) is both valid and sound - and consist of propositions that refer to verifiable claims, in everyday language use speakers are more concerned with expressing their stance, and they use direct argumentative ICCs to motivate certain attitudinal assessments, i.e. interpretations rather than verifiable claims. Importantly, such direct arguments are much more economical than the full-blown classic arguments. A mere conditional clause, unaccompanied by a main clause, suffices to have a stretch of the preceding discourse (i.e. the trigger) interpreted as part of (i) the consequent of a conditional claim and (ii) the conclusion of a modus ponens form of argument, specifically as the propositional content that is qualified by the speaker's (implied) attitudinal assessment.

Indirect argumentative ICCs, by contrast, set up a different pattern of propositional logic, i.e. the argumentative form of denying the antecedent. Just like the modus ponens form, it has two premises, the first of which is the conditional claim that $p$ implies $q(p \rightarrow q)$. The second premise, however, is that $\mathrm{p}$ is not true. From these two premises it is inferred that q is not true either. Indirect argumentative ICCs, we contend, convey the denial of $\mathrm{p}$ - through a backshifted predictive protasis - in a formally invalid argument, and orient to the conclusion that q does not hold either. As characteristic of ICCs, q is never fully explicitly expressed. In the case of proarguments, $q$ is interpreted to be the opposite of the negative evaluation coded in the trigger. In the case of counter-arguments, q combines the propositional content of the trigger with the speaker's attitudinal qualification of it that is implied by the construction-in-context. In (16) we restate example (2) in terms of the propositional form of denying the antecedent. Two classic examples are included as well (in italics).

(16) $\quad \mathrm{p} \rightarrow \mathrm{q}$

$\operatorname{Not} p(\neg p)$

Hence, not q $(\neg q)$
If [he has to work weekends every week]p, then [it is understandable that she is angry $]_{\mathrm{q}}$

(a) If [Socrates is a man] $]_{p}$, then [Socrates is mortal] $q$

(b) If [it barks] , then [it is a dog] $]_{q}$

He does not have to work weekends every week

(a) Socrates is not a man

(b) It doesn't bark

Hence, it is not understandable that she is angry

(a) Hence, Socrates is not mortal

(b) Hence, it is not a dog 
Arguments like these are invalid in formal logic, because the truth of the premises does not guarantee the truth of the conclusion. While the fallacy is most obvious for (16a), as its conclusion is clearly false, it is less clear for (16b), since its conclusion may seem to be true. However, within informal logic arguments of denying the antecedent form can still have legitimate uses to the extent that "the argument provides some reason for its conclusion" (Duarte d'Almeida and MacDonald 2016: 36-37; emphasis in original). And this is exactly what the indirect argumentative ICCs do in the everyday language examples we have come across so far, which - to our minds - present convincing arguments; they do not strike us as fallacies. In (2), rewritten in (16), the argument set up by the ICC provides some reason for speaker B's lack of understanding of the she-person's anger referred to in the trigger, but there may be other reasons as well (which are not considered). At the same time, the indirect argument rebuts just one line of argumentation, but not all potential arguments for a different conclusion. It suggests that one sufficient condition is not fulfilled, but there might be others. Imagine that the sheperson got angry because people had insulted her on the basis of her ethnic background. In that case, speaker B may not have shown a similar lack of understanding. If we apply this to (10), we can see that the speaker's indirect argument targets only one of several potential arguments about the reported recommendation to send Lies to first grade. As suggested by one of the anonymous referees, one might imagine an argument to the effect that since her two best friends of the same age start school, then - even if she is small and insecure - it would be cruel not to send her to first grade together with them. Crucially, that argument has not been invalidated by the speaker's indirect argument produced in (10).

The way the argumentative ICCs compare to classic forms of propositional logic nicely supports Mercier and Sperber's (2011) claim that humans do not reason to improve knowledge and make better decisions, but that the function of reasoning is basically argumentative. Humans, who by evolution are more dependent on communication and more vulnerable to miscommunication than any other species, reason to devise and evaluate arguments that serve to convince their fellow humans of their views, rather than to find the truth. The observation that we needed to include the speaker's (implied) attitudinal qualification to restate the ICCs as classic arguments in (15) and (16) substantiates Mercier and Sperber's (2011) claim. Conversely, their claim - which is backed up by different sorts of experimental evidence - lends support to the importance we attach to attitudinal qualification and semantic prosody in our analysis of argumentative ICCs.

\section{Conclusions}

This article aimed to present a descriptive analysis of a hitherto undescribed type of independent conditional clauses, and thereby to extend the inventory of independent conditional clauses that has been developed in the literature. We have shown that ICCs in Dutch can be used for argumentative purposes, and we distinguished between two subtypes of argumentative ICCs. Direct arguments express a 'given' premise on the basis of which a conclusion about the speaker's standpoint regarding a preceding trigger can be drawn. Indirect arguments, by contrast, formulate an assumption on the basis of which a particular conclusion concerning the speaker's standpoint could have been made. The hypothetical backshift that is typical of this 
construction type signals the existence of strong counterevidence to the assumption, so that an opposite conclusion is implied. While direct arguments are single-layered, indirect ones involve two layers, a propositional one and a counterfactual one.

The two types of argumentative ICCs were also shown to differ in terms of argumentative orientation. Whereas direct arguments function as pro-arguments, motivating the speaker's implied approval or acceptance of the preceding trigger, indirect arguments can also function as counter-arguments, motivating the speaker's implied disapproval or rejection of the trigger. The implied conclusions (acceptance versus rejection) were shown to be inspired by attitudinal assessments of various kinds, depending on the contents of the trigger and ICC (e.g. deontic, mirative, or boulomaic). Indirect arguments can also function as pro-arguments. In this use they nevertheless orient towards a conclusion that involves a negative evaluation, so that in general indirect arguments were argued to show negative semantic prosody. By focusing on the interactional dynamics of the discourse, tracing whether the interlocutors producing the trigger and the ICC were identical or not, we were able to point to several rhetorical effects of the two argument types.

Invoking Dancygier's (1993, 1998) typology of conditionals, we proposed that the semantic and pragmatic differences between the two argument types emanate from them realizing protases of different types of conditional constructions. Direct arguments were analyzed as independent instances of epistemic non-predictive conditionals, while indirect arguments were argued to instantiate independent instances of hypothetical predictive conditionals (Dancygier 1993, 1998). Table 1 brings together the main features discussed in Sections 2 and 3.

\section{[Insert Table 1 about here]}

Putting the contrast between direct and indirect arguments even more sharply, we made an excursion to the domain of propositional logic, and argued that - together with the propositional content in the trigger - the former are interpreted to launch an argument of the modus ponendo ponens form, whereas the latter set up the argumentative form of denying the antecedent, which is a formally fallacious type, but is recuperated within informal logic as a legitimate argument form on the condition that it offers some reason for its conclusion (cf. Duarte d'Almeida and MacDonald 2016: 36-37). This analysis allowed us to explain the observation that indirect arguments - in the propositional layer - refer to a condition that is sufficient for acceptance (which is reflected in the presence of scalar elements) and that they hence target only one line of argumentation for rebuttal, leaving an open set of other arguments invalidated.

An important difference with the conditional constructions focused on in Dancygier (1993, 1998) and with the classic argumentative forms is that in the constructions studied here the conclusion is never explicitly expressed, as the argumentative ICCs lack main clauses. Their conditional form orients towards a particular conclusion regarding the speaker's standpoint, but leaves it to be inferred by the addressee. This is why we argued that the use of independent conditionals to express an argument implies more addressee involvement than syntactically complete conditionals or classic proposition-logic argument forms. 
While this article focused on Dutch data, D'Hertefelt (2015) has observed that the two argument types studied are observable in Swedish and English as well; her German data included direct arguments only. We propose that our descriptions of the semantic and pragmatic properties of direct and indirect argumentative ICCs, as well as their links with argumentative forms used in formal and informal logic apply to these other Germanic languages equally.

Finally, this study also raises a number of questions for further research. D'Hertefelt (2015) has encountered argumentative ICCs in a number of Germanic languages, but so far these argumentative functions have not been described for any of the Romance languages for which descriptions of independent conditionals are available, or any non-European language. Therefore, further exploration is needed to check the cross-linguistic availability of this argumentative strategy.

Another question which we have not tackled here concerns the theoretical status of the constructions studied, i.e. whether argumentative ICCs can be considered instances of conditional 'insubordination'. Insubordinated constructions use markers normally associated with subordination, but function as independent clauses (Evans 2007: 367). At first sight our data seem to be cases in point, since they are marked as subordinate by the conditional subordinator als and verb-final word order, but they occur without an accompanying main clause. However, in contrast to the better-described instances of ICCs, like requests or wishes, it is hard to posit conventionalized meanings for argumentative ICCs; these seem to be highly schematic and - with indirect arguments - also depend on the argumentative orientation. The context of the ICC, especially the trigger, is crucial to the more specific meaning of the ICC, and would have to be integrated in its larger constructional template. Because of their reliance on context we believe that argumentative ICCs are less 'independent' than more constructionalized instances of conditional insubordination. D'Hertefelt and Verstraete (2014) have shown for independent complement clauses that not all these constructions are instances of insubordination, but that there is an alternative mechanism that leads to 'independent' subordinate clauses alike, i.e. the mechanism of dependency shift. We think a similar study on independent conditional clauses is needed, since it would add to both our understanding of insubordination and related mechanisms, and to our knowledge of how different uses of independent conditional clauses relate to each other.

\section{List of abbreviations}

2

3

COND

DEM

INF

INTERJ

NEG

PAPA

PL

PRS

PRT second person

third person

conditional

demonstrative

infinitive

interjection

negation

past participle

plural

present

particle 


\section{Corpus}

CGN, Corpus Gesproken Nederlands ('Spoken Dutch Corpus'). Nederlandse Taalunie. More information online at http://lands.let.ru.nl/cgn/ (Jan 20 2017).

\section{References}

Boogaart, Ronny \& Kim Verheij. 2013. Als dát geen insubordinatie is! De pragmatiek van zelfstandige conditionele zinnen [If that isn't insubordination! The pragmatics of independent conditional clauses]. In Theo Janssen \& Jan Noordegraaf (eds.), Honderd jaar taalwetenschap. Artikelen aangeboden aan Saskia Daalder bij haar afscheid aan de Vrije Universiteit. [One hundred years of linguistics. Articles presented to Saskia Daalder upon her leaving the Free University of Amsterdam], 13-28. Amsterdam \& Münster: Stichting Neerlandistiek VU, Nodus Publikationen.

Clark, Herbert H. 1996. Using language. Cambridge: Cambridge University Press.

Dancygier, Barbara. 1993. Interpreting conditionals: Time, knowledge, and causation. Journal of Pragmatics 19. 403-434.

Dancygier, Barbara. 1998. Conditionals and prediction: Time, knowledge, and causation in conditional constructions. Cambridge: Cambridge University Press.

DeLancey, Scott. 2001. The mirative and evidentiality. Journal of Pragmatics 33(3). 369-382.

D'Hertefelt, Sarah. 2015. Insubordination in Germanic: A typology of complement and conditional constructions. Leuven: University of Leuven PhD Dissertation.

D’Hertefelt, Sarah \& Jean-Christophe Verstraete. 2014. Independent complement constructions in Swedish and Danish: Insubordination or dependency shift? Journal of Pragmatics 60. 89-102.

Duarte d'Almeida, Luís \& Euan MacDonald. 2016. Denying the antecedent: The fallacy that never was, or sometimes isn't? Informal Logic 36(1). 26-63.

Evans, Nicholas. 2007. Insubordination and its uses. In Irina Nikolaeva (ed.), Finiteness. Theoretical and empirical foundations, 366-431. Oxford: Oxford University Press.

Evans, Nicholas \& Honoré Watanabe (eds.). 2016. Insubordination (Typological Studies in Language 115). Amsterdam \& Philadelphia: John Benjamins.

Gentens, Caroline, Ditte Kimps, Kristin Davidse, Gilles Jacobs, An Van linden \& Lot Brems. 2016. Mirativity and rhetorical structure: The development and prosody of disjunct and anaphoric adverbials with 'no' wonder. In Gunther Kaltenböck, Evelien Keizer \& Arne Lohmann (eds.), Outside the clause. Form and function of extra-clausal constituents [Studies in Language Companion Series 178], 125-156. Amsterdam: John Benjamins.

Günthner, Susanne. 1999. Wenn-Sätze im Vor-Vorfeld: Ihre Formen und Funktionen in der gesprochenen Sprache [If/When-clauses in sentence-initial position: Their forms and functions in spoken language]. Deutsche Sprache 27(3). 209-235.

Harder, Peter. 1997. Functional semantics: A theory of meaning, structure, and tense in English. Berlin \& New York: Mouton de Gruyter.

Kaltenböck, Gunther. 2016. On the grammatical status of insubordinate if-clauses. In Gunther Kaltenböck, Evelien Keizer \& Arne Lohmann (eds.), Outside the clause: Form and 
function of extra-clausal constituents (Studies in Language Companion Series 178), 341378. Amsterdam \& Philadelphia: John Benjamins.

Laury, Ritva, Camilla Lindholm \& Jan Lindström. 2013. Syntactically non-integrated conditional clauses in spoken Finnish and Swedish. In Eva Havu \& Irma Hyvärinen (eds.), Comparing and contrasting syntactic structures. From dependency to quasi-subordination (Mémoires de la Société Néophilologique de Helsinki 86), 231-270. Helsinki: Société Néophilologique.

Mercier, Hugo \& Dan Sperber. 2011. Why do humans reason? Arguments for an argumentative theory. Behavioral and Brain Sciences 34(2). 57-74.

Morley, John \& Alan Partington. 2009. A few Frequently Asked Questions about semantic or evaluative - prosody. International Journal of Corpus Linguistics 14(2). 139-158.

Nuyts, Jan. 2005. The modal confusion: On terminology and the concepts behind it. In Alex Klinge \& Henrik H. Müller (eds.), Modality: Studies in form and function, 5-38. London: Equinox.

Nuyts, Jan. 2006. Modality: Overview and linguistic issues. In William Frawley (ed.), The expression of modality (The Expression of Cognitive Categories 1), 1-26. Berlin: Mouton de Gruyter.

Nuyts, Jan, Pieter Byloo \& Janneke Diepeveen. 2010. On deontic modality, directivity, and mood: The case study of Dutch mogen and moeten. Journal of Pragmatics 42(1). 16-34.

Oppenrieder, Wilhelm. 1989. Selbständige Verb-Letzt-Sätze: Ihr Platz im Satzmodussystem und ihre intonatorische Kennzeichnung [Independent verb-final clauses: Their position in the sentence type system and their intonational marking]. In Hans Altmann, Anton Batliner \& Wilhelm Oppenrieder (eds.), Zur Intonation von Modus und Fokus im Deutschen, 163-244. Tübingen: Niemeyer.

Panther, Klaus-Uwe \& Linda L. Thornburg. 2003. Metonymies as natural inference and activation schemas: The case of dependent clauses as independent speech acts. In KlausUwe Panther \& Linda L. Thornburg (eds.), Metonymy and pragmatic inferencing, 127147. Amsterdam: Benjamins.

Patard, Adeline. 2014. Réflexions sur l'origine de l'insubordination. Le cas de trois insubordonnées hypothétiques du français [Reflections on the origin of insubordination. The case of three hypothetical insubordinates in French]. Langages 196. 109-130.

Schwenter, Scott. 2016. Meaning and interaction in Spanish independent si-clauses. Language Sciences 58. 22-34.

Sinclair. J. 2004. Trust the text: Language, corpus and discourse. London/New York: Routledge.

Simon-Vandenbergen, Anne-Marie \& Karin Aijmer. 2007. The Semantic field of modal certainty: A Corpus-based study of English adverbs. Berlin: Mouton.

Stirling, 1999. Isolated if-clauses in Australian English. In David Lee \& Peter Collins (eds.), The clause in English. In honour of Rodney Huddleston (Studies in Language Companion Series 45), 275-297. Amsterdam \& Philadelphia: John Benjamins.

Sweetser, Eve. 1990. From etymology to pragmatics. Cambridge: Cambridge University Press. Vallauri, Edoardo Lombardi. 2004. Grammaticalization of syntactic incompleteness: Free conditionals in Italian and other languages. SKY Journal of Linguistics 17. 189-215. 
van Eemeren, Frans H., Rob Grootendorst, Francisca Snoeck Henkemans, J. Anthony Blair, Ralph H. Johnson, Erik C.W. Krabbe, Christian Plantin, Douglas N. Walton, Charles A. Willard, John Woods \& David Zarefsky. 1996. Fundamentals of argumentation theory. A handbook of historical backgrounds and contemporary developments. Mahwah: Lawrence Erlbaum Associates.

Van linden, An. 2012. Modal adjectives: English deontic and evaluative constructions in diachrony and synchrony (Topics in English Linguistics 75). Berlin: De Gruyter Mouton.

Van linden, An \& Jean-Christophe Verstraete. 2011. Revisiting deontic modality and related categories: A conceptual map based on the study of English modal adjectives. Journal of Pragmatics 43. 150-163.

Van linden, An, Kristin Davidse \& Lennart Matthijs. 2016. Miracles and mirativity: From lexical it's a wonder to grammaticalised it's no wonder in Old English. Leuvense Bijdragen - Leuven Contributions in Linguistics and Philology 99-100. 385-409.

Weuster, Edith. 1983. Nicht-eingebettete Satztypen mit Verb-Endstellung im Deutschen [Nonembedded clause types with verb-final word order in German]. In Klaus Olszok \& Edith Weuster (eds.) Zur Wortstellungsproblematik im Deutschen, 7-88. Tübingen: Narr. 
TRIGGER (T): $\quad$ I paid pensioners to carry my groceries to my car.

POSSIBLE SPEAKER

STANDPOINT:

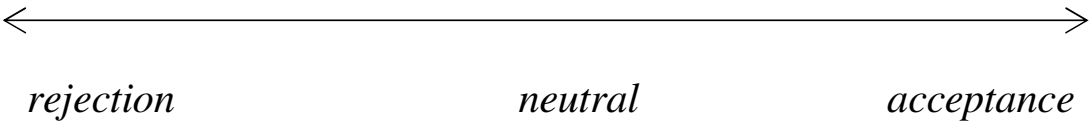

EVAlUATION OF T: $\quad$ Negative ('I sometimes feel troubled')

'Uncontroversial' speaker standpoint:

Rejection of T

ARGUMENT IN ICC: $\quad$ This practice is these people's income.

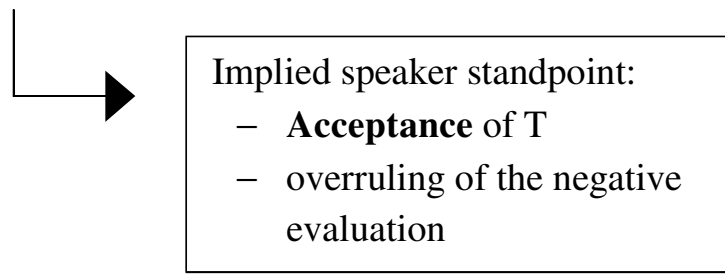

Figure 1: Schematic representation of direct arguments 
TRIGGER (T):

The CLB told my daughter to send Lies to first grade.

POSSIBLE SPEAKER

STANDPOINT:

$\begin{array}{lll}\text { rejection } & \text { neutral } & \text { acceptance } \\ \text { non-compliance } & \text { neutral } & \text { compliance }\end{array}$

\section{ARGUMENT IN ICC:}

propositional layer: Lies is a big and tough girl.

Uncontroversial speaker standpoint:

Acceptance of T

Compliance with $\mathrm{T}$

counterfactual layer: Lies is not a big and tough girl.

Implied speaker standpoint:

Rejection of $\mathrm{T}$

Non-compliance with $\mathrm{T}$

Figure 2: Schematic representation of indirect counter-arguments 
TRIGGER (T): $\quad$ My previous GP was not competent (or less competent than a layperson); this was irritating and dangerous.

POSSIBLE SPEAKER

STANDPOINT:

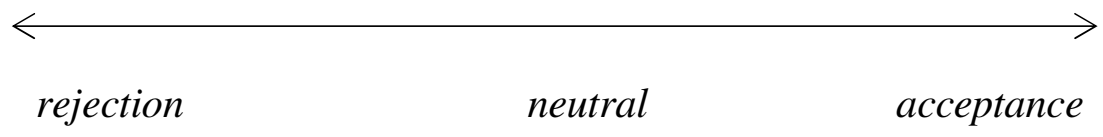

ARGUMENT IN ICC:

propositional layer: That was all (i.e. the GP did not make any more mistakes).

Uncontroversial speaker standpoint:

Rejection of $\mathrm{T}$

counterfactual layer: That was not all (i.e. the GP did make more mistakes).

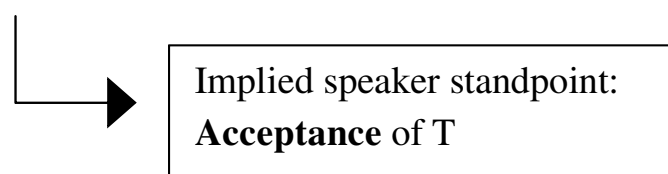

Figure 3: Schematic representation of indirect pro-arguments 
Table 1: Differences between two types of ICCs informed by Dancygier's $(1993,1998)$ typology

\begin{tabular}{|c|c|c|}
\hline \multirow[t]{2}{*}{ Parameters } & Direct argumentative ICC & Indirect argumentative ICC \\
\hline & $\begin{array}{c}\text { Epistemic non-predictive } \\
\text { conditionals }\end{array}$ & $\begin{array}{c}\text { Hypothetical predictive } \\
\text { conditionals }\end{array}$ \\
\hline Interpretation of verb forms & No backshift & Backshift \\
\hline $\begin{array}{l}\text { Type of unassertability } \\
\text { signaled }\end{array}$ & $\begin{array}{l}\text { Epistemic distance between } \\
\text { speaker and contextually } \\
\text { given } \mathrm{p}\end{array}$ & $\begin{array}{l}\text { Unassertability of prediction } \\
\text { because of impossible } p\end{array}$ \\
\hline $\begin{array}{l}\text { Type of semantic relation } \\
\text { between the propositions in } \\
p \text { and } q\end{array}$ & $\begin{array}{l}\text { Inferential: } p \text { expresses an } \\
\text { assumption on the basis of } \\
\text { which the speaker arrives at } \\
\text { a conclusion in } q\end{array}$ & $\begin{array}{l}\text { Conditional: } \mathrm{p} \text { expresses an } \\
\text { assumption on the basis of } \\
\text { which the speaker arrives at } \\
\text { a prediction in } \mathrm{q} \text { (sequential } \\
\text { and causal relations between } \\
\mathrm{p} \text { and } \mathrm{q} \text { ) }\end{array}$ \\
\hline
\end{tabular}




\section{Bionotes}

Sarah D'Hertefelt obtained her PhD in Linguistics at the University of Leuven, and currently teaches English proficiency at the University of Brussels (VUB, Belgium). Her research interests include complementation and conditionality, insubordination and Germanic languages.

An Van linden is assistant professor of English language and linguistics at the University of Liège and affiliated researcher in the research unit Functional and Cognitive Linguistics at the University of Leuven. Her research interests include the analysis of clause combining, mood and modality, information structure and grammaticalization in the NP, from a diachronic and a synchronic perspective, in the Germanic languages as well as in typologically diverse languages. She is also describing Harakmbut, an unclassified language from the Peruvian Amazon.

Addresses for correspondence:

Sarah D'Hertefelt

VUB - Toegepaste taalkunde, room 313

Pleinlaan 5

1050 Brussel

Belgium

sarah.dhertefelt@gmail.com

An Van linden (Corresponding author)

Université de Liège Bât. A2, bureau 6/16

Place Cockerill 3-5

4000 Liège

Belgium

an.vanlinden@ulg.ac.be 